\title{
Information Quality and Absorptive Capacity in Service and Product Innovation Processes
}

\author{
Helinä Melkas, Tuomo Uotila, and Anne Kallio \\ Lappeenranta University of Technology, \\ Lahti School of Innovation, Lahti, Finland
}

\section{helina.melkas@lut.fi; tuomo.uotila@lut.fi; anne.kallio@lut.fi}

\begin{abstract}
All innovative activity involves generation and use of knowledge. Knowledge is therefore often assumed to be the most valuable resource of a firm. Creation of new knowledge is conceptualized as conversion, recombination, and exchange of existing knowledge. The concept of absorptive capacity becomes intriguing here. It was originally defined as an organization's ability to value, assimilate and apply new knowledge. Absorptive capacity requires learning capability and develops problem-solving skills. Two types of absorptive capacity have been identified: (i) potential absorptive capacity is important in acquiring and assimilating external knowledge; and (ii) realized absorptive capacity refers to functions of transformation and exploitation of the knowledge that has been obtained. Absorptive capacity is crucial when pondering questions about futureknowledge adaptation in firms and other organizations; higher absorptive capacity enables easier crossing of structural holes in the innovation system. This study investigates ways in which information quality is related to absorptive capacity when designing service and product innovations. The study includes theoretical considerations and three case analyses based on empirical data collected in Finland. The research responds to arising societal and academic interest by combining several research fields (information quality, absorptive capacity and innovation studies). Designing service and product innovations is a challenging task that requires a good knowledge basis in today's increasingly complex operational environment.
\end{abstract}

Keywords: Information Quality (IQ), Absorptive Capacity, Knowledge Conversion, Service Innovation, Product Innovation

\section{Introduction}

All innovative activity - understood as trying out of a new opportunity or action (Witt, 1996), involves generation and use of knowledge. Knowledge is therefore often assumed to be the most valuable resource of a firm. Creation of new knowledge is conceptualized as recombination and exchange of existing knowledge (Teigland \& Wasko, 2003). Brökel and Binder (2007) recently

Material published as part of this publication, either on-line or in print, is copyrighted by the Informing Science Institute. Permission to make digital or paper copy of part or all of these works for personal or classroom use is granted without fee provided that the copies are not made or distributed for profit or commercial advantage AND that copies 1) bear this notice in full and 2) give the full citation on the first page. It is permissible to abstract these works so long as credit is given. To copy in all other cases or to republish or to post on a server or to redistribute to lists requires specific permission and payment of a fee. Contact Publisher@InformingScience.org to request redistribution permission. discussed two types of knowledge transfers: intended and unintended. In intended knowledge transfers, actors actively seek knowledge, whereas unintended knowledge transfers occur when an individual "stumbles upon" knowledge. They focused on the tacit type of knowledge in innovation economics. Their research showed that knowledge search processes of an individual are biased toward regionally available 
knowledge, and an agent's social embeddedness fosters overrepresentation of regional actors in her/his set of potential knowledge sources.

This kind of policy definition (intended - unintended) is consistent with, for example, the findings of Rondé and Hussler (2005). In their study dealing with knowledge flows and localized learning processes, they found results suggesting that competences dedicated to external interactions have a more important impact on innovation than internal competences. They also found that unintended knowledge flows have less influence on innovation than deliberate ones. Hence, their analysis advocated innovation policies dedicated to support networks of regional actors.

The case of organizations may be similar; knowledge transfers of a firm, for instance, might well be intended or unintended. The concept of absorptive capacity becomes intriguing here. The concept was originally defined by Cohen and Levinthal (1990) as an organization's ability to value, assimilate and apply new knowledge. Kim (1998) argued that absorptive capacity requires learning capability and develops problem-solving skills; learning capability is the capacity to assimilate knowledge for imitation, and problem-solving skills are the capacity to create new knowledge for innovation.

Zahra and George (2002) defined two different types of absorptive capacity: (i) potential absorptive capacity is important in acquiring and assimilating external knowledge; and (ii) realized absorptive capacity refers to functions of transformation and exploitation of the knowledge that has been obtained. Both are important in innovation processes: potential absorptive capacity enables exploration of knowledge (often) over the weak ties of an innovation system, and realized absorptive capacity secures exploitation (often) in the weak ties of the system. Absorptive capacity is crucial when pondering questions about future-knowledge adaptation in firms and other organizations that belong in innovation systems and networks; higher absorptive capacity enables easier crossing of structural holes in the innovation system.

Lee and Strong (2004) saw knowledge in general as a prerequisite for work. When they discussed knowledge for work, they meant knowledge about work processes and the resulting work performance. They also noted that, whereas conventional research has recognized the importance of knowledge and the corresponding organizational learning, actual relationships and patterns of various modes of knowledge for specific performance have not been explored. According to them, controversy remains about how modes of knowledge are involved in work practice. For example, pre-existing declarative knowledge has been found to play a role in absorbing and creating new knowledge in innovation activities (Cohen \& Levinthal, 1990). Lee and Strong's (2004) view was that modes of knowledge are conceptually separate, but, during work, they are used interactively. They saw a clear need for further empirical investigation into how knowledge works in specific work domains. The work domain for our inquiry into knowledge is innovation processes.

Modes of knowledge may also be discussed in relation to knowledge conversion processes (e.g., Harmaakorpi \& Melkas, 2005; Melkas \& Harmaakorpi, 2008; Uotila, Melkas \& Harmaakorpi, 2005). Knowledge conversion in networked innovation processes has been originally focused on by Nonaka and Takeuchi (1995). Their four-phase SECI model of knowledge conversion had the aim of causing a learning spiral where a collective learning process increases knowledge in the network. Knowledge conversion takes place in certain forums or arenas ( $b a$ in Japanese) that can be concrete or virtual places where knowledge conversion occurs. Different kinds of knowledge processes need different kinds of bas.

The field of information quality (IQ) may provide new insights into absorptive capacity, knowledge conversion and design of innovations (cf. Melkas \& Harmaakorpi, 2008; Uotila \& Melkas, 2008). Although information quality has gained increasing attention during the last few years among researchers and practitioners, this attention has primarily concentrated on more established 
and stable environments than innovation processes within or among firms and other organizations. Such processes may have very little to do with information systems and information technology that have usually been focused on in research concerning information quality.

It has been noted that an important goal of information quality is to increase customer and stakeholder satisfaction - better information quality leads to better customer service (English, 1999; Huang, Lee \& Wang, 1999). We argue that better information quality may lead to improved absorptive capacity and thus more and better innovations. The relationship between information quality and absorptive capacity is un-researched, to our knowledge. The particular character of innovation processes - including knowledge conversion processes - places additional challenges on this relationship.

The sphere of innovation processes could be compared to that of foresight studies. Melkas and Uotila (2007) noted that for many researchers of data, information and knowledge quality, futures research and foresight studies probably do not seem relevant. These researchers often represent exact sciences, where technical solutions can be found. Although gaps between IQ researchers and less exact fields appear to be narrowing, the basic philosophy does still remain different. The primary goal in foresight studies - or in innovation processes and studies - is not to produce accurate forecasts - or faultless services and products with guaranteed demand - but rather to participate in development, affect and contribute to it, and thus to open up and widen actors' mental horizons (Cuhls, 2003; Salo, 2000; cf. Melkas \& Uotila, 2007).

By combining several research fields (information quality, absorptive capacity, and innovation studies) in a novel way, this study investigates ways in which information quality is related to absorptive capacity when designing service and product innovations. The study includes theoretical considerations and three case analyses that are based on empirical data collected in Finnish organizations from various sectors. Designing service and product innovations is a challenging task that requires a good knowledge basis in increasingly complex operational environments. Given the increasing importance of innovation, this research is relevant for those interested broadly in information, knowledge, and management.

\section{Background}

\section{Information and Knowledge, and Their Quality}

Pierce, Kahn, and Melkas (2006) discussed the hierarchy of data, information, and knowledge, and quality dimensions associated with those. They noted that most scholars have referred to a datum as the most basic descriptive element. Whether it is symbolized as a number, text, or figure, a datum essentially represents a perception or measurement about some object of interest. By itself, a datum's value typically lacks content, meaning, or intent. Data is the plural of datum and its usage is more common because for the most part, organizations work with collections of datum. Although some use the term data interchangeably with information, others consider information to be more than just data. Information is viewed as the output of some process that interprets and manipulates data into some prescribed format. According to Pierce and her colleagues, complicated information products are particularly vulnerable to quality issues regarding their reliability, organization, content, accessibility, and presentation.

While some view knowledge as information that has been further enriched so its value, context, and meaning are enhanced, others consider knowledge as being intrinsically different from either data or information products. The idea that knowledge is more than information stems from the notion that knowledge is more process than product. The knowledge process occurs when an individual mentally synthesizes together an assortment of inputs: information experiences, beliefs, 
relationships, and techniques to determine what a specific situation means and how to handle it (Pierce et al., 2006).

Although the hierarchy of data, information and knowledge is important both theoretically and in practice (cf., e.g., Melkas \& Harmaakorpi, 2008; Melkas \& Uotila, 2007; Uotila \& Melkas, 2008), in this study, the concepts of information and knowledge are used side-by-side instead of listing them each time. The reasons are that (i) knowledge is the concept that is more often mentioned in the innovation literature, and (ii) the concept of information quality, again, is used in the literature more often than knowledge quality, and thus it is used also in this study for the sake of clarity. It is assumed that similar quality dimensions can be studied in relation to information and knowledge (cf. Pierce et al., 2006).

There are many categories used to explain knowledge, such as

- Explicit knowledge: Knowledge expressed as words or numbers. This type of knowledge is codified and well defined.

- Tacit knowledge: Knowledge expressed as insights and intuitions. This type of knowledge is highly personal and hard to formalize.

- Self-transcending knowledge: The ability to sense the presence of potential, to see what does not yet exist. It can also be described as tacit knowledge prior to its embodiment (Scharmer, 2001).

Or as follows

- Declarative knowledge: Facts, know-what comprehension

- Explanatory knowledge: Rationalization, know-why knowledge

- Procedural knowledge: Instructions, know-how understanding

- General/ organizational knowledge: Knowledge that is easily transferred and possessed by large numbers of people.

- Specific/ individual knowledge: Knowledge that is difficult to transfer and thus is possessed by very few people. (Pierce et al., 2006.)

Gibbons and colleagues (1994), again, defined two classes of knowledge used in innovation processes. Mode 1 is hierarchical and tends to preserve its form, while Mode 2 is more heterarchical and transient by nature. One of the key contrasts between the two modes is that in Mode 1, problem solving is carried out following codes of practice relevant to a particular discipline and problem solving, while in Mode 2, knowledge activity is organized around a particular application and is more diffuse by nature. Gibbons et al. (1994) reported an epoch change in knowledge activity in innovation networks with a shift from Mode 1 to Mode 2 knowledge creation (Howells, 2000).

Data, information products and knowledge are of high quality if they are fit for their intended use in conducting business operations, decision making and planning (Pierce et al., 2006). Three common approaches that have been used to identify associated quality dimensions are shown in Table 1 . This study mainly applies the intuitive approach in the case analyses. 
Table 1 - Common approaches used to identify information (data) quality dimensions (source: Pierce et al., 2006).

\begin{tabular}{|c|c|c|}
\hline Approach & Definition & Examples \\
\hline Intuitive & $\begin{array}{l}\text { Selection of quality attributes in a specific study is based on the indi- } \\
\text { vidual's experience or intuitive understanding about what attributes } \\
\text { are important. }\end{array}$ & $\begin{array}{l}\text { Wang, Lee, Pi- } \\
\text { pino \& Strong, } \\
1998\end{array}$ \\
\hline System & Focuses on how the output of a process may become deficient. & $\begin{array}{l}\text { Wand \& Wang, } \\
1996\end{array}$ \\
\hline Empirical & $\begin{array}{l}\text { Collects input from consumers to determine the characteristics they } \\
\text { use to assess whether the end product is fit for use in their tasks. }\end{array}$ & $\begin{array}{l}\text { Wang \& Strong, } \\
1996\end{array}$ \\
\hline
\end{tabular}

Lee, Strong, Kahn, and Wang (2002) provided an extensive review of academics' and practitioners' views of information quality. They noted that academic research included several types of studies. One provided overall coverage for the IQ construct by empirically developing the dimensions from information consumers, such as in the Wang and Strong study (1996). Zmud's study (1978) was an early empirical effort based on hard-copy reports. Another type developed their dimensions from literature reviews, i.e., the Delone and McLean (1992), Goodhue (1995), and Jarke and Vassiliou (1997) studies. By grouping all measures from other authors together, they hoped to cover all aspects of the IQ construct. The third type of study focused on a few dimensions that can be objectively defined; e.g., Ballou and Pazer (1985), and Wand and Wang (1996).

Practitioners, again, reported the dimensions and measures they use within organizations. The approach is generally not rigorous from a research viewpoint, but it provides some insight into their views. IQ practitioners include specialists within organizations, outside consultants, and vendors of products. As they focus on specific organizational problems, coverage of all IQ properties is not their primary intent. The IQ dimensions employed by them are driven by the context in which they are delivering IQ - more than does the research of academics. The contexts include, for example: data warehouse development, information quality tools for improving the quality of data input to databases, environments with multiple incompatible databases, and environments in which timely delivery of information is critical. The context influences the dimensions selected (Lee et al., 2002).

Information quality has been theoretically linked to innovation-related knowledge conversion processes by, for instance, Melkas and Harmaakorpi (2008) and Uotila and Melkas (2008). Even in the same technological field, the language in basic research may be so different from practicebased innovation processes that an innovation process could end before it has started, even if the innovation potential in the structural hole is obvious (Melkas \& Harmaakorpi, 2008). Each individual type of data, information and knowledge as well as each conversion phase may require different quality dimensions to be taken into consideration. Factors affecting the necessary quality dimensions are also the network, its structure, field of operation and objectives as well as the innovation process in question.

In innovation activities, knowledge conversion phases do not necessarily take place in a systematic order (cf. Nonaka \& Takeuchi, 1995). These activities proceed from highly vague and fragmented ideas to - at best - a more detailed and clear common understanding of the network, enabling practical action in the form of, for instance, designing a new mobile phone. The exploitation process is thus no longer taken care of by a very diffuse network, but in each process, criteria for data, information and knowledge quality are argued to be necessary. In other words, by means of looking into the concepts of bas, conversion phases and quality dimensions, innovation processes may be aided in practice (Melkas \& Harmaakorpi, 2008; Uotila \& Melkas, 2008). Quality dimen- 
sions for the quite different types of knowledge, especially tacit and self-transcending knowledge, are worth further research. Paying attention to these conversion processes appears to be particularly challenging, given the necessarily spontaneous and sometimes even chaotic nature of these processes in particular (Melkas \& Harmaakorpi, 2008).

\section{Absorptive Capacity and Innovation Creation}

Collective learning processes are nowadays emphasized in generating innovations. At the regional level, focus has been put on regional innovation systems, where different kinds of actors are involved in innovative processes (Cooke, 2001; Harmaakorpi \& Melkas, 2005). A regional innovation system consists of multi-actor innovation networks including actors with often quite different aims and knowledge interests (cf. Brökel \& Binder, 2007; Cooke, Uranga \& Etxebarria, 1998; Kostiainen, 2002). 'Innovation system' is a broad concept that extends over schools, universities, research institutions, industrial enterprises (the economic system), politicoadministrative and intermediary authorities (the political system) as well as formal and informal networks of actors of these institutions.

Innovations may be classified according to their "type". Schumpeter (1942) already distinguished between five different types: new products, new methods of production, new sources of supply, exploitation of new markets and new ways to organize business. Innovation itself is a process that can be mastered by everyone in the organization, and that can, and should, occur at different levels in the organization (or network) (Paalanen \& Konsti-Laakso, 2008). In order to create an environment that will allow and encourage people to provide their innovative ideas, an organization must provide a trusting, caring climate where all staff members feel an ownership for the innovative process. Therefore, it is essential to develop an organizational climate in which people participating in the change process feel safe in taking interpersonal risks, are encouraged to propose new ideas, discuss problems openly, and approach their work proactively (e.g., Baer \& Frese, 2003).

Innovation processes are sometimes chaotic by nature; they require and reflect a higher understanding of creativity and openness than a 'normal' product or service development process within an individual company. A closer look at them is taken in the case analyses. A conceptual discussion of innovation processes is beyond the scope of this study. To understand the characteristics of absorptive capacity as a dynamic capability in innovation processes, a closer look has to be taken at its different parts: acquisition, assimilation, transformation and exploitation of knowledge.

- Acquisition refers to an actor's capability to identify and acquire externally generated knowledge that is critical to its operations.

- Assimilation refers to the actor's routines and processes that allow it to analyze, process, interpret and understand the knowledge obtained from external sources.

- Transformation denotes an actor's capability to develop and refine the routines that facilitate combining existing knowledge and the newly acquired and assimilated knowledge.

- Exploitation as a capability is based on the routines that allow actors to refine, extend and leverage existing competencies or to create new ones by incorporating acquired and transformed knowledge into their operations (Zahra \& George, 2002).

According to these definitions, absorptive capacity is like a funnel where potential absorptive capacity (visionary capability) secures the newness and diversity of the necessary knowledge, whereas realized absorptive capacity (innovative capability) stands for operationalization of the new knowledge in the existing processes in order to make the actual innovation to take place. The difference between potential and realized absorptive capacity is however often blurred in practice. 
Zahra and George (2002) suggested that there is also a need for a special social interaction mechanism between assimilation and transformation processes.

Todorova and Durisin (2007) recently reviewed the literature concerning absorptive capacity and noted ambiguities and omissions in Zahra and George's work (2002). In light of that, Figure 1 illustrating absorptive capacity is based on the original Cohen and Levinthal's (1990) work.

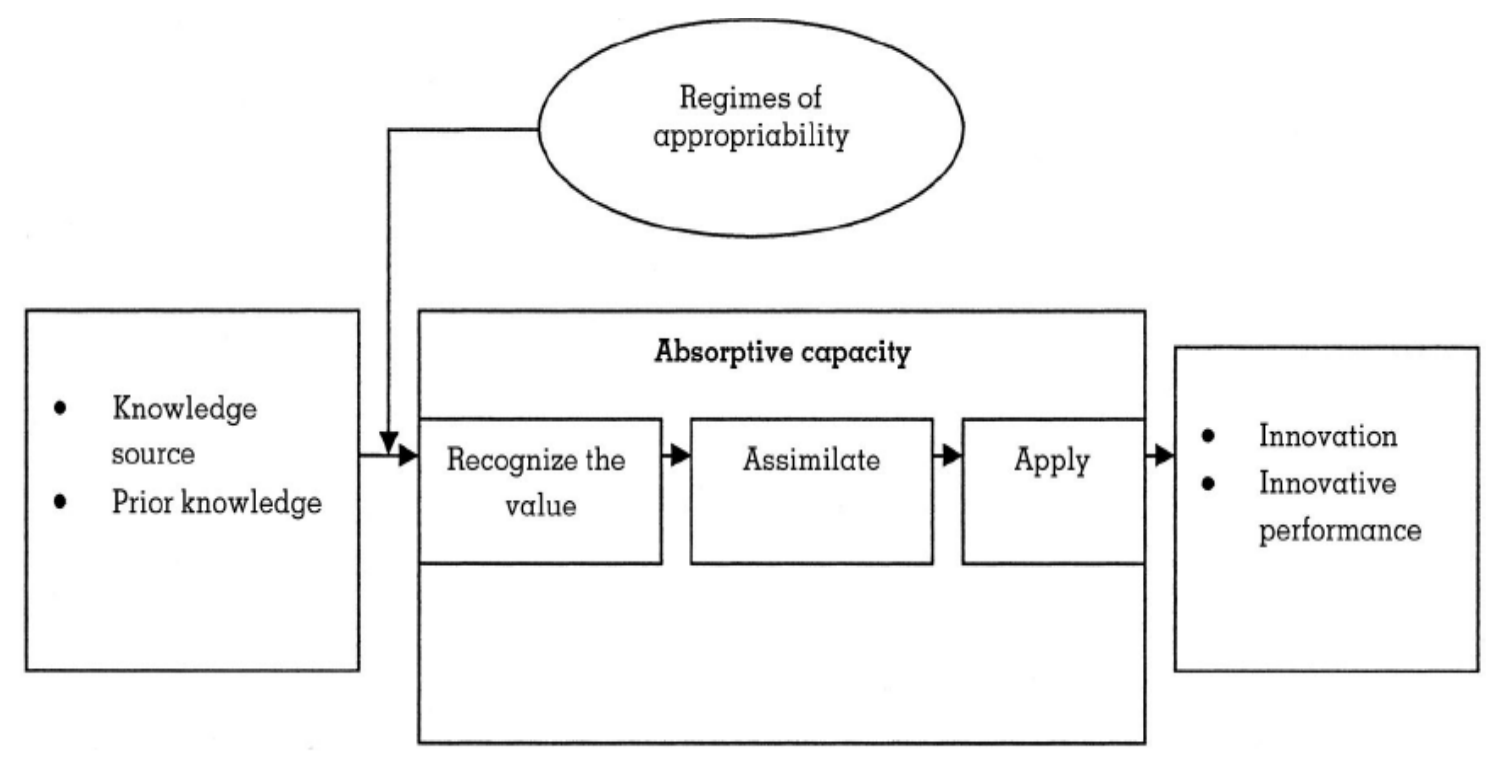

Figure 1 - A model of absorptive capacity based on Cohen \& Levinthal (1990) (source: Todorova \& Durisin, 2007, p. 775).

Besides two modes of knowledge (cf. Cohen \& Levinthal, 1990), the four parts of absorptive capacity (acquisition, assimilation, transformation ,and exploitation of knowledge) are here claimed to be related to knowledge conversion processes (explicit - tacit - self-transcending). Understanding and benefiting from the existence of different modes of knowledge and knowledge conversions appear as necessary for high absorptive capacity.

\section{Rationale, Purpose, and Methodology}

In order to (i) find out whether better information quality may lead to improved absorptive capacity, and more and better innovations, (ii) contribute to understanding the role of absorptive capacity in innovation creation, and (iii) find new practical ways to enhance absorptive capacity, relevant dimensions and impacts of information (/knowledge) quality are assessed by means of three qualitative case studies - two on service and one on product innovation processes. The issues to be looked into are

- most relevant IQ dimensions for absorptive capacity

- types of impact of information quality on absorptive capacity

- relationship between information quality, absorptive capacity and knowledge conversion processes

Information quality dimensions that are utilized in the analysis are listed in Table 2. 
Table 2 - Information quality dimensions and their definitions (source: Wang \& Strong, 1996).

\begin{tabular}{|c|c|}
\hline Believability & The extent to which information is accepted or regarded as true, real and credible. \\
\hline Value-added & $\begin{array}{l}\text { The extent to which information is beneficial and provides advantages from its } \\
\text { use. }\end{array}$ \\
\hline Relevancy & The extent to which information is applicable and helpful for the task at hand. \\
\hline Accuracy & The extent to which information is correct, reliable and certified free of error. \\
\hline Interpretability & $\begin{array}{l}\text { The extent to which information is in appropriate language and units and the in- } \\
\text { formation definitions are clear. }\end{array}$ \\
\hline Ease of understanding & $\begin{array}{l}\text { The extent to which information is clear without ambiguity and easily compre- } \\
\text { hended. }\end{array}$ \\
\hline Accessibility & The extent to which information is available or easily and quickly retrievable. \\
\hline Objectivity & The extent to which information is unbiased (unprejudiced) and impartial. \\
\hline Timeliness & The extent to which the age of the information is appropriate for the task at hand. \\
\hline Completeness & $\begin{array}{l}\text { The extent to which information is of sufficient breadth, depth and scope for the } \\
\text { task at hand. }\end{array}$ \\
\hline Traceability & $\begin{array}{l}\text { The extent to which information is well documented, verifiable and easily attrib- } \\
\text { uted to a source. }\end{array}$ \\
\hline Reputation & $\begin{array}{l}\text { The extent to which information is trusted or highly regarded in terms of its } \\
\text { source or content. }\end{array}$ \\
\hline $\begin{array}{l}\text { Consistent representa- } \\
\text { tion }\end{array}$ & $\begin{array}{l}\text { The extent to which information is always presented in the same format and is } \\
\text { compatible with previous information. }\end{array}$ \\
\hline Cost-effectiveness & The extent to which the cost of collecting appropriate information is reasonable. \\
\hline Ease of operation & $\begin{array}{l}\text { The extent to which information is easily managed and manipulated (i.e., updated, } \\
\text { moved, aggregated, reproduced, customized). }\end{array}$ \\
\hline $\begin{array}{l}\text { Variety of information } \\
\text { and information sources }\end{array}$ & $\begin{array}{l}\text { The extent to which information is available from several differing information } \\
\text { sources. }\end{array}$ \\
\hline Concise representation & $\begin{array}{l}\text { The extent to which information is compactly represented without being over- } \\
\text { whelming (i.e., brief in presentation, yet complete and to the point). }\end{array}$ \\
\hline Access security & The extent to which access to information can be restricted and hence kept secure. \\
\hline $\begin{array}{l}\text { Appropriate amount of } \\
\text { information }\end{array}$ & $\begin{array}{l}\text { The extent to which the quantity or volume of available information is appropri- } \\
\text { ate. }\end{array}$ \\
\hline Flexibility & $\begin{array}{l}\text { The extent to which information is expandable, adaptable and easily applied to } \\
\text { other needs. }\end{array}$ \\
\hline
\end{tabular}

The three cases focused on are described in the case analysis section. They are

- two different kinds of service innovation processes in the Finnish public health care sector, conducted in collaboration with private and non-governmental organization (NGO) sectors

- product innovation processes (and their variations) in a large firm in the Finnish food industry

All the cases concern processes that have taken place within the innovation system of Lahti region in Finland (cf. Melkas \& Uotila, 2007). The Lahti region, located close to the Helsinki met- 
ropolitan area, is a special case among the Finnish city regions. It is the fifth largest region in Finland, and it is one of the most important industrial centres in Finland. It suffered heavily from the economic recession of the 1990s, resulting in major changes in its economic and social structure. The Lahti region is by far the largest Finnish region without its own university, and its regional rate of R\&D investments is relatively low. The "middle-sizedness" of the region, the relatively low R\&D intensity, the networked structure of the regional knowledge base, and the closeness of the most competitive Finnish regions have given rise to a "network-facilitating innovation policy model" in the Lahti region (cf. Linna, Melkas \& Hennala, in press).

The special tasks of the network-facilitating innovation policy are to enhance practice-based innovation processes and enable efficient transfer of scientific knowledge and expertise to those processes. Innovations are sought for especially at the interfaces of the regional knowledge-base and the scientific knowledge-base found in the surrounding research centres. It can be described as a well-grounded assumption or, in a loose sense, "a theory" of the relevant means by which the companies and the public and third sectors in the region can produce innovations and increase regional competitiveness and well-being (Harmaakorpi \& Tura, 2006; Lakes, 2005). The network-facilitating innovation policy emphasizes the social nature of innovation environments, where innovations are found in unorthodox combinations and interfaces of actors, disciplines, institutions, industries and regions. The policy is combined with other economic development policy activities (Linna et al., in press).

\section{Case Analyses: Descriptions and Results}

Cases number 1 and 2 represent loosely structured, partly virtual innovation processes, whereas case number 3 represents more rigorously organized processes within one company (although operating in collaboration with external actors).

\section{Case 1: A Smart Home Innovation Process}

An innovation session was organised in April 2006 at Lahti as part of a national productivity project. There were some 40 participants in this session from municipalities, the third sector such as non-governmental organizations; universities, polytechnics, the local science and business park, and alike. The session resulted in recommendations for how to reform elderly care services. One of the recommendations of the expert group was introduction of smart homes for elderly people. This was the beginning of the smart home innovation process.

This was subsequently chosen as a regional priority for improving productivity, and about a year later, a separate pilot of smart homes was launched. It was then implemented in four different housing service units for elderly people in three Finnish municipalities: Lahti, Nastola and Hollola. Smart homes were in use during short-term housing periods related to, for instance, end of hospitalization, holidays of caring relatives and assessment of living and housing conditions.

More than 60 different assistive devices and technologies were in use in the smart homes. During the pilot, it was investigated how this type of activity affects processes of elderly care - and how these processes affect the activity in question. It was also investigated whether the customers considered the technologies and devices as well as their design as "their own" and to be of help in their daily lives. The pilot period lasted for about nine months in 2007.

Research was conducted within the smart homes pilot on the basis of survey questionnaires $(\mathrm{n}=20)$, interviews with customers ( 4 interviews) and care personnel ( 5 interviews), feedback from 14 companies involved in the pilot as well as discussions in a heterogeneous multi-sectoral and multi-professional expert group that steered the pilot (Melkas, Pekkola, Enojärvi \& Makkula, 2008). The results of the pilot gave new knowledge that is being used in the region after the pilot to develop elderly care service processes further and clarify their ownership so that separately 
managed cross-functional processes could be built with participants from different sectors to operate alongside organizations of elderly care services. The pilot also resulted in improved consciousness of care personnel as to use of innovative assistive devices in elderly care. Case number 1 thus consists of interlinked innovation subprocesses at individual, organizational, municipal, and multi-sectoral network levels, although the individual level is not studied here due to the organizational character of the theme of absorptive capacity.

\section{Case 2: A Hotel Service Innovation Process}

This innovation process also focused on elderly care services. It had been noted that no intermediary housing service existed for persons who had been hospitalized and no longer needed hospital care but were not able to cope at home yet. Coping at home may be impossible due to, for instance, absence of necessary assistive devices such as safety alarm systems. Likewise, no intermediary housing service existed for elderly persons whose home had to be renovated (e.g., plumbing renovations and other time-consuming major renovations). For these purposes, a novel hotel service concept was designed in close collaboration between public sector health-care authorities of City of Lahti, three middle-sized hotels at Lahti as well as third sector service providers (e.g., a foundation providing home care services). It means that a person may, if s/he wishes and the health condition allows it, stay at a hotel close to the hospital for a few days between end of hospitalization and returning home. Alternatively, a person who has to move out of her/his home due to a major renovation may stay at a reasonably priced hotel for a longer period of time, and there is no need to move into an old-age home, for instance.

The innovation process started with initial idea creation and informal discussions at Lahti Science and Business Park and Lahti Chamber of Commerce in 2004-05. The beginning was slow. An actual pilot to develop the service innovation further was started in early 2007 , and it ended in August 2008. The innovation process was steered by an expert group consisting of public authorities from social and health care and individual hospitals, representatives of hotels, nongovernmental service providers and of neighbouring smaller municipalities as well as researchers. The group met about once a month. The researchers followed the innovation development process closely during the whole implementation period. They conducted an assessment on the basis of survey and interview data consisting of 8 customer interviews, 7 interviews with professionals implementing the service, and 24 survey questionnaires that were filled in by customers, hotels, non-governmental service providers, and near relatives of customers, where appropriate (Melkas $\&$ Pekkola, 2008). The novel service concept was adopted for continuous use and has been further developed in multi-sectoral collaboration after the end of the pilot.

\section{Case 3: Product Innovation Processes in the Food Industry}

In a large Finnish company that produces foodstuffs, innovation processes have been particularly cherished. Case number 3 focuses on different types of product innovation processes within this nation-wide company. Interviews with six key persons participating in such processes within the company were conducted in the autumn of 2008. They represented different professions and backgrounds - from top management to shop-floor employees. Two product innovation processes - with varying characteristics such as duration, starting point, aim, participating actors, and other characteristics - were studied in detail (Uotila, Melkas \& Paalanen, 2009). This analysis also focused particularly on the topic of knowledge conversion processes. For reasons of confidentiality, no further background information on the company's products or processes is given here.

\section{Central Elements of Innovation Processes}

The innovation processes were divided into four central elements (according to the classification of Hennala, 2008): 
- a service or product development process designing innovative solutions

- a decision-making process, in which the innovative solutions developed are brought to the attention of relevant decision-makers (for instance, leading municipal authorities)

- an empowerment process that enhances implementation of innovations brought about in the service or product development process

- a research and documentation process, the task of which is to produce information, knowledge and know-how for planning and implementing development activities

The element of knowledge conversion processes cuts across all these four elements, as conversions take place in all of them. The above-mentioned four elements were found to be in operation simultaneously. They could be discerned in all the different cases. With regard to each element, information and knowledge transfers and conversions play a crucial role, although types of information and knowledge may be quite different. Absorptive capacity is also vital with regard to all the four elements, but may concern different actors or networks of actors. For instance, in case number 2, the service development process included, in particular:

- Lahti Science and Business Park

- Lahti Chamber of Commerce

- City of Lahti, social and health care services

The decision-making process, again, included, in particular:

- Lahti Science and Business Park

- City of Lahti, social and health care services

- Owners and managers of hotels

The empowerment process included all the relevant actors:

- Lahti Science and Business Park

- public authorities from social and health care and individual hospitals

- representatives of hotels

- representatives of non-governmental service providers

- representatives of neighbouring smaller municipalities

- researchers

- customers and their near relatives

- the general public

The research and documentation process within case no. 2 included, in particular:

- City of Lahti, social and health care services

- The researchers

- A service provider that took care of reservations for the service

The large amount of different actors places great challenges on absorptive capacity and its enhancement, as well as on information quality.

\section{Most Relevant IQ Dimensions for Absorptive Capacity}

The interview and survey data and discussions in the steering groups (where relevant) were analyzed with the help of the information quality dimensions in Table 2 . The interviews and discus- 
sions were documented in memos and analyzed qualitatively. The steps in the analysis were as follows

- identifying the relevant actors in each case for the four elements of the innovation process

- identifying their requirements and needs for the knowledge that was transferred and converted in the innovation process in question

- identifying the relevant IQ dimensions on the basis of Table 2

- identifying impacts of information quality on the basis of the previous steps, and investigating them further in light of the different cases

This analysis also benefited from IQ analysis techniques introduced in Melkas (2004). The survey data, where relevant, were utilized to support the analysis. Absorptive capacity and IQ dimensions have not, to the authors' knowledge, been combined in detail in previous analyses. Cases number 1 and 2 were in many ways rather similar. In Table 3, the results of the three cases are combined.

On the basis of the analysis, information quality was clearly a relevant concept with regard to all parts of absorptive capacity. All the IQ dimensions analyzed were not relevant, however; access security is not included in any cell of Table 3 . This is in line with the change of the innovation paradigm from relatively closed innovation processes within individual organizations to more open innovation processes that also may include end-users or customers of innovative services or products.

The most commonly relevant IQ dimensions in the whole analysis were the following:

- ease of understanding (mentioned 16 times)

- relevancy (14)

- value-added (13)

- interpretability, completeness, and appropriate amount of information (12)

- accuracy, and concise representation (11)

- reputation (10)

- objectivity (9)

- believability (8)

- timeliness (7)

Less relevant in the context of innovation processes were ease of operation, variety of information and information sources, and flexibility (all mentioned 6 times), accessibility (5), costeffectiveness (4), traceability (3) and consistent representation (2).

The most relevant quality dimensions can be relatively readily assigned in one's mind to knowledge (not only information), which is also in line with the context of this study - innovation processes and absorptive capacity. Open innovation processes involving increasingly complex multisectoral and multi-professional networks are quite likely to highlight the need for ease of understanding, interpretability, and believability, for instance. 


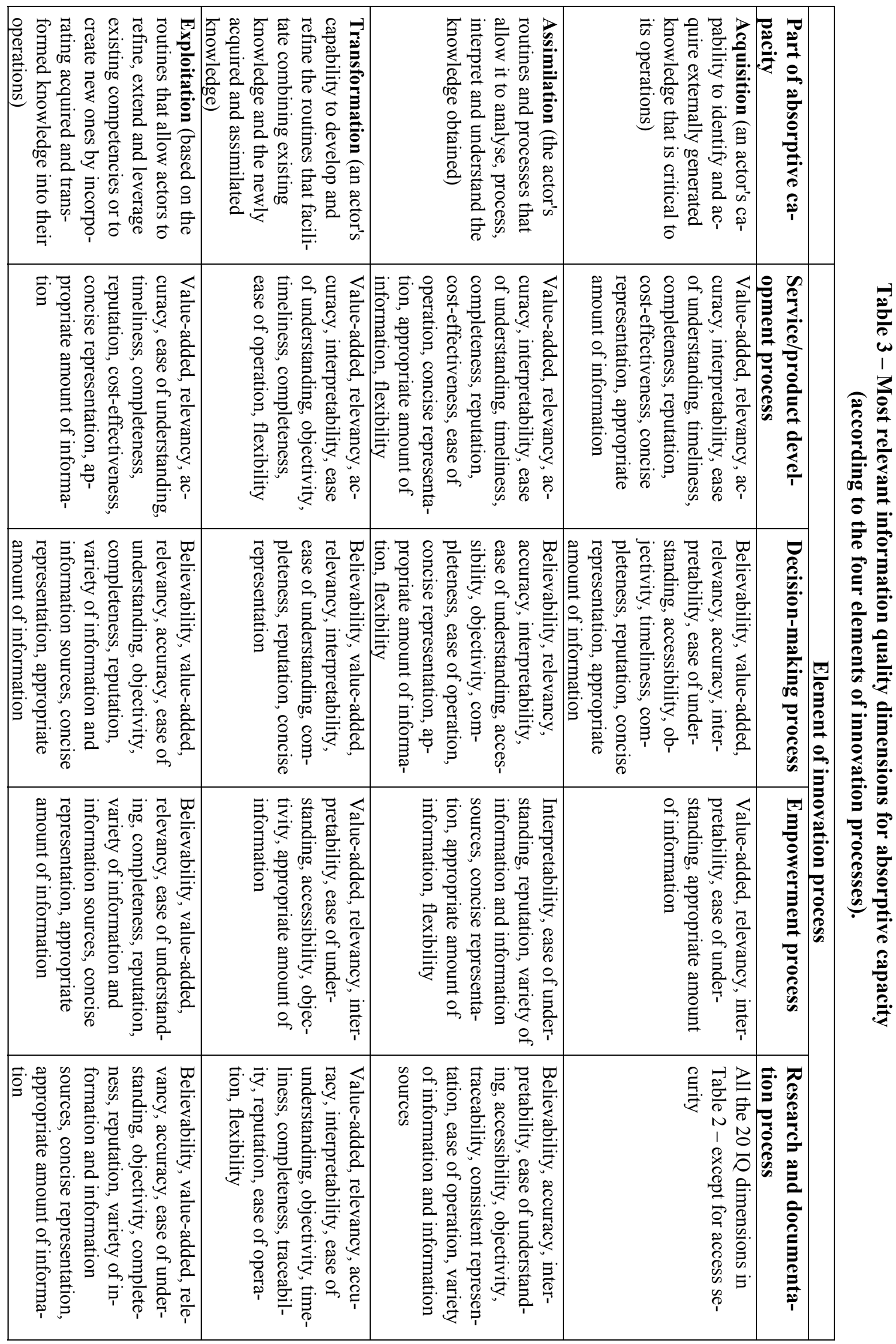




\section{Types of Impact of Information Quality on Absorptive Capacity}

As to the types of impact of information quality on absorptive capacity, it was found out in the research that by taking quality dimensions into close consideration in innovation processes, absorptive capacity might be relatively easily enhanced. For instance, in the acquisition phase, an actor's capability to identify and acquire externally generated knowledge that is critical to its operations might well be improved, should the other actors in the innovation network pay close attention to ease of understanding of the information/knowledge that they bring to the network - by means of using appropriate concepts and less complicated language than they might use with their own colleagues at their workplace.

In the assimilation phase, again, the actor's routines and processes that allow it to analyze, process, interpret, and understand the knowledge obtained could be developed by means of having an appropriate amount of information/ knowledge that is represented concisely. This kind of thinking is very demanding in a heterogeneous innovation network that may only have a faint idea of what it is developing or innovating, but should and could be everyone's responsibility in the network.

In transformation and exploitation phases, value-added and relevancy of the knowledge provided may be of help. On the other hand, the innovation processes studied have shown that they may become considerably slower or even stop altogether (for some period of time), if the empowerment process, for instance, does not function. In the empowerment process, taking into account quality dimensions related to knowledge is also vital in order to create a common understanding and commitment to collaborative action.

According to the research results, with regard to smooth knowledge conversion processes as a means of enhancing absorptive capacity, IQ dimensions such as flexibility, ease of understanding and interpretability enable multi-faceted and multiple uses of knowledge and thus improve possibilities of smooth knowledge conversion.

\section{Discussion and Conclusion}

Innovation was traditionally related to new product development in R\&D departments where innovations and inventions are generated inside of a company by its engineers and researchers. Today, innovations are often generated in networks, where actors with different backgrounds are involved in the innovation process. Innovations require abilities to interact, learn collectively and build trusting relations between the innovating partners. Innovativeness depends on the innovation network's functioning rather than on an individual actor's progress in a particular scientific field (cf. Linna et al., in press.) Absorptive capacity is an integral part of innovativeness.

This study focused on the relationship between information quality and absorptive capacity. It also took into account knowledge conversion processes. Most relevant information quality dimensions for absorptive capacity were identified with the help of three cases, and impacts of information quality on absorptive capacity were discussed. The results showed that information quality was clearly a relevant concept with regard to all parts of absorptive capacity. All the IQ dimensions analyzed were not relevant, however. The finding that, for instance, access security was not relevant is in line with the change of the innovation paradigm towards increasingly open innovation processes that also may include end-users of innovative services or products. The results also showed that by taking quality dimensions into close consideration in innovation processes, absorptive capacity might be enhanced relatively easily. In the acquisition phase, for example, an actor's capability to identify and acquire important externally generated knowledge might well be improved, if the other actors in the innovation network pay careful attention to ease of understanding of the information/ knowledge that they bring to the network. 
Taking into account information quality dimensions may also be of help in skilful utilization of structural holes and weak links (Burt, 2004), as well as of different types of distances and proximities between innovation collaborators (such as cognitive, social, geographic, etc.; cf. Harmaakorpi, Tura \& Melkas, in press). It has often been seen within the innovation system of the Lahti region how difficult it is to reach a fruitful dialogue between actors whose knowledge interests are very far from each other. The innovation potential may be clear, but the innovation processes are inadequate due to poor communication and absorptive capacity. Information quality dimensions could be taken up, for example, by information and knowledge brokers (cf. Burt, 1997; 2004).

In an innovation process, it is crucial to make actors see the issues focused on in a new light. Although the tradition related to IQ research and practice is in many ways different, the innovation context offers an intriguing environment also for further IQ research for the benefit of firms, the public sector and the third sector.

This research brought together the topics of innovation studies, absorptive capacity and information quality. Combining these research fields corresponds to arising societal needs as well as academic interest. The importance of innovations is more and more emphasized these days at various levels - national, international, regional and micro-level (individual organizations). Improving absorptive capacity and quality of information/ knowledge requires a holistic approach to the entire innovation process. The results of this research may be applied in further research (in other types of cases) as well as in practice in planning new innovation processes.

\section{References}

Baer, M., \& Frese, M. (2003). Innovation is not enough: Climates for initiative and psychological safety, process innovations, and firm performance. Journal of Organizational Behaviour, 24(1), 45-68.

Ballou, D. P., \& Pazer, H. L. (1985). Modeling data and process quality in multi-input, multi-output information systems. Management Science, 31(2), 150-162.

Brökel, T., \& Binder, M. (2007). The regional dimension of knowledge transfers - A behavioral approach. Industry and Innovation, 14(2), 151-175.

Burt, R. S. (1997). The contingent value of social capital. Administrative Science Quarterly, 42, 339-365.

Burt, R. S. (2004). Structural holes and good ideas. American Journal of Sociology, 110(2), 349-399.

Cohen, W., \& Levinthal, L. (1990). Absorptive capacity: A new perspective on learning and innovation. Administrative Science Quarterly, 35, 128-152.

Cooke, P. (2001). Regional innovation systems, clusters, and the knowledge economy. Industrial and Corporate Change, 10(4), 945-974.

Cooke, P., Uranga, M., \& Etxebarria, G. (1998). Regional innovation systems: An evolutionary perspective. Environment and Planning, A, 30, 1563-1584.

Cuhls, K. (2003). From forecasting to foresight processes-New participative foresight activities in Germany. Journal of Forecasting, 22, 93-111.

Delone, W. H., \& McLean, E. R. (1992). Information systems success: The quest for the dependent variable, Information Systems Research, 3(1), 60-95.

English, L. P. (1999). Improving data warehouse and business information quality. New York, NY: John Wiley \& Sons.

Gibbons, M., Limoges, C., Nowotny, H., Schwarzman, S., Scott, P., \& Trow, M. (1994). The new production of knowledge. London: Sage.

Goodhue, D. L. (1995). Understanding user evaluations of information systems, Management Science, 41(12), 1827-1844. 
Harmaakorpi, V., \& Melkas, H. (2005). Knowledge management in regional innovation networks: The case of Lahti, Finland. European Planning Studies, 13(5), 641-659.

Harmaakorpi, V., \& Tura, T. (2006). Practice-based innovation activities and network-facilitating innovation policy. Proceedings: Innovation pressure - Rethinking competitiveness: Policy and the society in a globalised economy, International ProAct Conference, 15-17 March 2006, Tampere, Finland.

Harmaakorpi, V., Tura, T., \& Melkas, H. (in press). Regional innovation platforms. In R. Boschma, P. Cooke, F. Toedtling, \& R. Martin (Eds.), Handbook on regional innovation and growth. Forthcoming in 2010 .

Hennala, L. (2008). Kehittäminen, tutkimus ja oppiminen - innovatiivisen työskentelytavan mahdollistaminen kuntasektorilla [Development, research and learning - Enabling an innovative way of working in the municipal sector]. In H. Kotila, A. Mutanen, \& M.-L. Kakkonen (Eds.), Opetuksen ja tutkimuksen kiasma [The chiasma of teaching and research]. Helsinki: Edita. (In Finnish).

Howells, J. (2000). Knowledge, innovation and location. In J. R. Bryson, P. W. Daniels, N. Henry, \& J. Pollard (Eds.), Knowledge, space, economy. London/New York: Routledge.

Huang, K. T., Lee, Y. W., \& Wang, R. Y. (1999). Quality information and knowledge. Upper Saddle River, NJ: Prentice Hall.

Jarke, M., \& Vassiliou, Y. (1997). Data warehouse quality: A review of the DWQ project. Proceedings of the 1997 Conference on Information Quality. Cambridge, MA, 299-313.

Kim, L. (1998). Crisis construction and organisational learning: Capability building in catching-up at Huyndai Motor. Organization Science, 9, 506-521.

Kostiainen, J. (2002). Urban economic development policy in the network society. Tampere: Tekniikan Akateemisten Liitto ry.

Lakes. (2005). Lahti Region Business Strategy 2005-2008. Lahti: Lakes. Retrieved 18 May 2010 from http://www.lahtisbp.fi/easydata/customers/lahti/files/Julkaisut/lakes_businessstrategy eng.pdf

Lee,Y. W., \& Strong, D. M. (2004). Knowing-why about data processes and data quality. Journal of Management Information Systems, 20(3), 13-39.

Lee, Y. W., Strong, D. M., Kahn, B. K., \& Wang, R. Y. (2002). AIMQ: A methodology for information quality assessment. Information \& Management, 40(2), 133-146.

Linna, P., Melkas, H., \& Hennala, L. (in press). Designing and implementing regional innovation policy in the public sector: Tools for triggering organisational process innovation. International Journal of Innovation and Regional Development.

Melkas, H. (2004). Towards holistic management of information within service networks: Safety telephone services for ageing people. Doctoral dissertation. Espoo: Helsinki University of Technology, Department of Industrial Engineering and Management. Retrieved 18 May 2010 from http://lib.tkk.fi/Diss/2004/isbn9512268868/

Melkas, H., \& Harmaakorpi, V. (2008). Data, information and knowledge in regional innovation networks: Quality considerations and brokerage functions. European Journal of Innovation Management, 11(1), 103-124.

Melkas, H., \& Pekkola, S. (2008). Turvallista yöpymistä hotellissa: Lahden hotellipilottipalveluinnovaation kehitys ja tulokset 2007-2008. Hankkeen arviointiraportti [Safe accommodation in hotels: Development and results of the 'hotel pilot' service innovation at Lahti, 2007-2008]. Lahti: Lahden tiede- ja yrityspuisto. (In Finnish)

Melkas, H., Pekkola, S., Enojärvi, S., \& Makkula, S. (2008). Vanhusten hyvä kotona asuminen: tutkimusta kuntatuottavuudesta, älykodeista ja apuvälinepalveluprosesseista [Good living at home of older people: Research on municipal productivity, smart homes and service processes related to assistive devices]. Lahti: Lappeenrannan teknillinen yliopisto, Lahden yksikkö. (In Finnish) 
Melkas, H., \& Uotila, T. (2007). Quality of data, information and knowledge in technology foresight processes. Proceedings of the Twelfth International Conference on Information Quality (ICIQ-07), Cambridge, Massachusetts: MIT.

Nonaka, I., \& Takeuchi, H. (1995). The knowledge creating company: How Japanese companies create the dynamics of innovation. New York: Oxford University Press.

Paalanen, A., \& Konsti-Laakso, S. (2008). Innovaatiohaavi organisaation innovaatiokyvykkyyden kehittäjänä [Innovation catcher as developer of organizations' innovative capability]. In V. Harmaakorpi, \& H. Melkas (Eds.), Innovaatiopolitiikkaa järjestelmien välimaastossa [Innovation policies in between systems]. Acta no. 200. Helsinki: Suomen Kuntaliitto/ Lappeenrannan teknillinen yliopisto. (In Finnish)

Pierce, E., Kahn, B., \& Melkas, H. (2006). A comparison of quality issues for data, information, and knowledge. In M. Khosrow-Pour (Ed.), Emerging trends and challenges in information technology management: Proceedings of the 2006 Information Resources Management Association Conference. 17th IRMA International Conference, Washington, DC, USA, May 2006, 21-24.

Rondé, P., \& Hussler, C. (2005). Innovation in regions: What does really matter? Research Policy, 34, $1150-1172$.

Salo, A. (2000). Teknologian arviointi ja ennakointi (Technology assessment and foresight). In T. Lemola (Ed.), Näkökulmia teknologiaan (Perspectives into technology; in Finnish). Helsinki: Gaudeamus.

Scharmer, C. O. (2001). Self-transcending knowledge: Organizing around emerging realities. In I. Nonaka \& D. Teece (Eds.), Managing industrial knowledge: Creation, transfer and utilization (pp. 68-90). London: Sage Publications.

Schumpeter, J. A. (1942). The theory of economic development. London, UK: Oxford University Press.

Teigland, R., \& Wasko, M. M. (2003). Integrating knowledge through information trading: Examining the relationship between boundary spanning communication and individual performance. Decision Sciences, 34(2), 261-286.

Todorova, G., \& Durisin, B. (2007). Absorptive capacity: Valuing a reconceptualization. Academy of Management Review, 32(3), 774-786.

Uotila, T., \& Melkas, H. (2008). Complex knowledge conversion processes and information quality in regional innovation networks. Knowledge and Process Management, 15(4), 224-234.

Uotila, T., Melkas, H., \& Harmaakorpi, V. (2005). Incorporating futures research into regional knowledge creation and management. Futures, 37, 849-866.

Uotila, T., Melkas, H., \& Paalanen, A. (2009). A confidential unpublished report on a case company's innovation processes. Lahti: Lappeenranta University of Technology, Lahti School of Innovation. (In Finnish)

Wand, Y., \& Wang, R. Y. (1996). Anchoring data quality dimensions in ontological foundations. Communications of the ACM, 39(11), 86-95.

Wang, R. Y., Lee, Y., Pipino, L., \& Strong, D. (1998). Manage your information as a product. Sloan Management Review, 39(4), 95-105.

Wang, R. Y., \& Strong, D. M. (1996). Beyond accuracy: What data quality means to data consumers. Journal of Management Information Systems, 12(4), 5-34.

Witt, U. (1996). Innovations, externalities and the problem of economic progress. Public Choice, 89, 113130.

Zahra, A. Z., \& George, G. (2002). Absorptive capacity: A review, reconceptualization, and extension. Academy of Management Review, 27(2), 185-203.

Zmud, R. (1978). Concepts, theories and techniques: An empirical investigation of the dimensionality of the concept of information. Decision Sciences, 9(2), 187-195. 


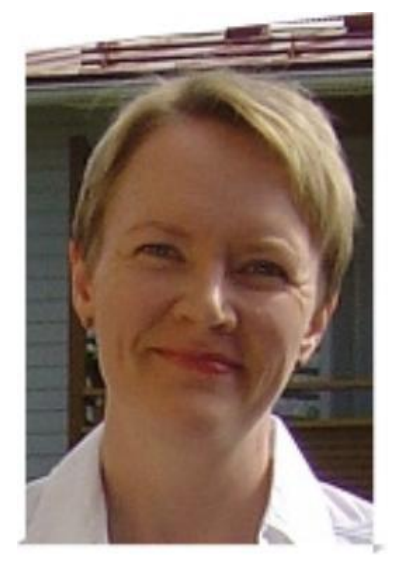

\section{Biographies}

Helinä Melkas, D.Sc. (Tech.), is Senior Research Fellow and Adjunct Professor at Lappeenranta University of Technology, Lahti School of Innovation, Lahti (Finland). She has worked previously at, for instance, Helsinki University of Technology, United Nations University, and in Switzerland and Japan. Her current research is related to information quality, knowledge management, social networks and innovation management.

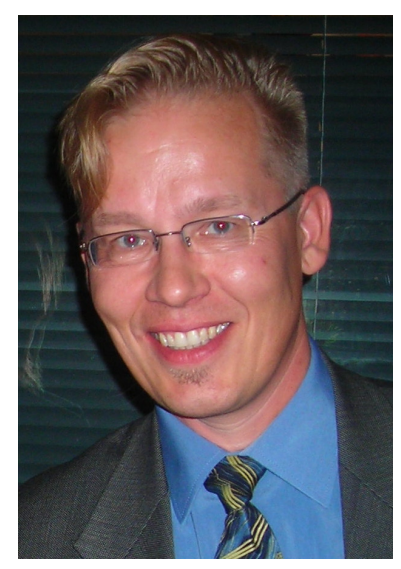

Tuomo Uotila, D.Sc. (Tech.), works as a Senior Researcher at Lappeenranta University of Technology, Lahti School of Innovation. He has previously worked as a researcher also at Turku School of Economics and Helsinki University of Technology. His current research interests are related to futures research and regional foresight, knowledge transfer and absorptive capacity. He has published several papers on these issues in international scientific journals.

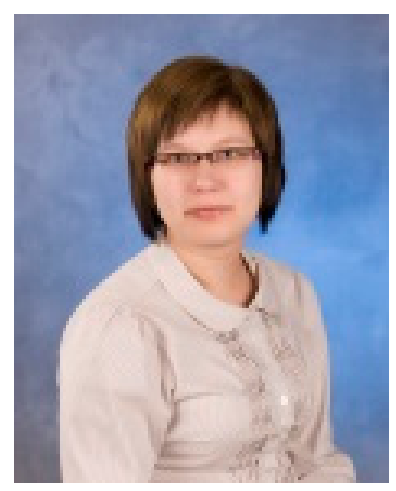

Anne Kallio, M.Sc. (Econ. \& Bus. Adm.) is a Researcher at Lappeenranta University of Technology, Lahti School of Innovation. Her Ph.D. studies focus on revealing the innovation potential that hides in everyday activities of organizations. She has conducted several action research processes in different types of organizations. Kallio's research interests are related to absorptive capacity, social capital and shopfloor employees' role in innovation. She has previously published in journals such as Urban Studies and International Journal of Technology Management. 